\title{
Repression, health care and ethics under apartheid
}

\author{
T L Dowdall Child Guidance Clinic, University of Cape Town, South Africa
}

Over the past twenty-five years torture by state security forces has escalated in South Africa. The scale of this abuse has impacted on the health professions, both medical and psychological, which have unavoidably been exposed to the casualties. Individual doctors and psychologists and the country's professional bodies have been forced to confront crucial ethical choices. This paper is about some of those choices and the schisms which they opened in the South African health professions. A brief contextual outline of the sociopolitical context within which repression, resistance and torture arose in South Africa will be followed by discussion of the challenges which civil rights abuses, including torture, have posed for health professions in this country; and how the professions have responded.

Torture in South Africa emerged as a logical development within an abusive social control system. This system - widely known as apartheid - was intended legally to entrench power and economic advantage in the hands of the white minority. South Africa had been settled from the mid-seventeenth century onwards by Britain and Holland. Wars of subjugation waged against the black peoples of the country were followed in the 20th century by coercive measures intended to bring blacks into the economy as cheap labour. When the Afrikaner Nationalist government came into power, after World War II, they instituted a rigorous formalisation of the loose racial discrimination practised previously.

The apartheid system inflicted enormous institutional violence on the black population of South Africa. In pursuit of racial separation without loss of cheap labour, millions of blacks were relocated to barren homelands where in order for families to survive physically they had to be fragmented by the migrant labour system. Those blacks permitted to live in 'white' areas were forced by the Group Areas Act to live in overcrowded soulless dormitory townships, prey to high levels of crime and violence, and far from their workplaces. In these circumstances blacks have succumbed in huge numbers to the diseases of poverty - such as tuberculosis or kwashiorkor - these effects aggravated further by inferior health and social services (1). They have been trapped in these circumstances by a separate education system overtly designed to disadvantage blacks as "hewers of wood and drawers of water'; and for decades they were prevented by the Job Reservation Act from taking up any but the lowest-paying work. Constructed within this system as 'untermenschen', blacks were slighted, patronised and psychologically undermined $(2,3)$.

$A$ vast and obstructive bureaucracy implemented the regulations of apartheid. Backing this bureaucracy are an efficient police and security police force and a sophisticated military which the state has not hesitated to use to quell the resistance which has erupted in recent decades under these intolerable conditions. Demonstrations have been put down with extreme force, and wide-ranging security legislation has allowed the state to ban publications, outlaw organisations, withdraw passports, banish people to remote areas, and in general criminalise political activity (4). The Internal Security Act and State of Emergency legislation allow the detention of persons without recourse to the courts and in conditions of secrecy (5). It is these provisions, together with de facto and legislated impunity enjoyed by security police, that have provided the climate in which torture can emerge and flourish (6).

As checks on the security police fell away, consistent reports of torture of political detainees began to surface, including violent assault, electric shock, 'hooding' and suffocation, forced prolonged exercise, death threats and prolonged solitary confinement $(7,8)$. Initially these abuses were mostly committed under the provisions of 'Section 29' (laws allowing detention of suspected political activists for interrogation) and relatively small numbers of activists were involved. From 1984/5 onwards, however, when widespread protest and civil conflict erupted, huge numbers of people were detained under the provisions of the State of Emergency. Violent assaults by members of the police and security forces were commonplace and seemed to be aimed at the intimidation of the general population (9).

Under these circumstances, members of the health professions came into direct contact with the work of the security police. Their responses to this testing situation brought into focus the ethical responsibilities of health professionals and publicly revealed the activities of the security police. 


\section{Torture and the medical profession}

Doctors' complicity in torture can take different forms, the most extreme of which involves the doctor as the actual torturer. South African doctors, as far as is known, have never performed that role. The problems in South Africa have arisen where certain district surgeons (doctors employed by the State Health Authorities) have passively collaborated with security police actions - sometimes to the point of gross and disgraceful neglect of the interests of their patients. Appropriate treatment has been withheld from sick or injured detainees, they have been pronounced fit for further abuse, and medical or autopsy reports have been falsified. These doctors monitored the excesses of the police in ways that would protect the police, regardless of their patients' interests (10).

A report by the Lawyers' Committee for Civil Rights Under Law (11) noted that some 50 detainees had died in detention between 1963 and 1977, in ways that were attributable to those excesses. Matters came to a head in 1977, however, when prominent political activist Steve Biko died as a result of torture and gross abuse whilst in security police custody. At the inquest it became clear that the two responsible district surgeons, Drs Ivor Lang and Benjamin Tucker were deeply implicated in Biko's death through gross neglect and falsification of medical records. Commenting on the complaints laid before the South African Medical and Dental Council, Rayner (12) notes that:

'... Dr Lang failed, apparently, to see the injury on the forehead on the occasion of his first and subsequent examinations, ... failed to attach any significance to the lip injury, or to other bruises and visible symptoms which Dr Lang admitted in court having noticed. He failed to ask the patient for his account of how these injuries were sustained. He did not prescribe any treatment, carry out any routine blood or urine analysis tests, or take the patient's temperature at any stage. $\mathrm{He}$ did not recommend to the police that $\mathrm{Mr}$ Biko should not be left lying on the floor on urine-soaked bedding. He failed to keep the patient under medical observation following Biko's transfer from Sydenham Prison Hospital to the Walmer Police Station. He did not keep Drs Hersch and Keeley fully informed about the patient's condition or of actions taken which may have affected his condition. He failed to insist upon proper hospitalisation, or to oppose Dr Tucker's acquiescence in the plan to send the patient to Pretoria. And only after Steve Biko died did Dr Lang make any notes or reports of his findings.'

When the matter came to a hearing of the South African Medical and Dental Council, however, this body voted that there was no prima facie evidence of disgraceful or improper conduct. This controversial decision was echoed by the Medical Association of
South Africa (MASA), provoking an outcry and resignations in protest by many MASA members. Indeed, MASA's stand led to its temporary expulsion from the World Medical Association. Faced with this clear dereliction of duty on the part of these bodies, a group of practitioners instituted a Supreme Court action and succeeded in having the medical council's resolution set aside and corrected (13). Finally, some seven years after the event, both Lang and Tucker were found guilty of disgraceful or improper conduct by the council, and were given token penalties.

An important aspect of this case was the extent to which political affiliation had infiltrated medical decision-making. Individual practitioners and the statutory and professional bodies themselves took positions and acted more in accordance with a political position than in terms of relatively independent medical ethics.

The Biko issue precipitated a split within the medical profession which had been building up for some time. Progressive doctors had for some time felt discontent with MASA's acquiescence with racial discrimination at all levels, but the association's conduct in this matter led directly to the formation of the alternative National Medical and Dental Association (NAMDA) in 1982. Members of this group took a clear stand in relation to detention and torture, provided medical assistance to ex-detainees and campaigned actively against the abuses which they encountered.

Fittingly, however, the next major public challenge to torture came from a young district surgeon. $\mathrm{Dr}$ Wendy Orr was assigned to work with State of Emergency detainees in Port Elizabeth where huge numbers of people were being arrested and brutally abused. When protests to her superiors were repeatedly deflected, Orr systematically gathered data within the prison system which substantiated allegations of a wide range of tortures perpetrated by the police. These included violent assault, electric shock, suffocation, exercise to exhaustion and a range of threats. She also gathered empirical data which demonstrated that the vast majority of detainees showed injuries consistent with their complaints (14). This evidence, supported further by a NAMDA study in Johannesburg (15), was crucial in refuting the state's argument that allegations of torture were fabricated to discredit the police.

With the support of human-rights lawyers, Orr made an urgent application to the Supreme Court to restrain the police from assaulting or threatening assault on detainees. She succeeded in this application, but the significance of her actions went far beyond the well-being of the detainees involved. As happened with the Biko case, torture was exposed to public condemnation, and the weight of international anger was brought to bear on the South African government. The scale of detention and torture began to decline as it became increasingly politically unprofitable. Likewise, the debate within the medical profession on 
the proper actions of doctors in the face of state abuse of their patients was taken further. Political partisanship up to now had taken the form of 'turning a blind eye' to torture. Orr's stand was made on the basis of professional ethics, and forced professional bodies and practitioners to acknowledge that, ethically, doctors could not be passive or acquiescent partners in torture.

Although there were no landmark events like the Biko or Orr cases within the psychological profession, essentially the same situation prevailed. Professional conferences and congresses had always shown bland inattention to the human and psychological effects of the oppressive social engineering experiment of apartheid, and in the face of evidence of torture preferred to continue that inattention. Attempts to raise these issues at congresses of the Psychological Association of South Africa raised heated arguments, walk-outs by sections of the audience and charges that certain members were attempting to intrude politics into what should be a professional forum.

A small number of concerned psychologists made contact with the Danish Rehabilitation and Research Centre for Torture Victims around 1983, and brought the training they received back to South Africa where it was passed on through workshops and developed for local conditions within small detainee treatment groups. The huge scale of abuses in the successive States of Emergency declared in the eighties prompted the formation of an anti-apartheid service-oriented organisation - the Organisation for Appropriate Social Service in South Africa; it also led to the formation of the Emergency Services Group - a nationwide organisation of doctors and counsellors concerned directly with providing services to survivors of torture and abuse by state security forces. As in the medical field, these alternative groups always formed a tiny minority - but during the 1980 s their public opposition to apartheid and torture gradually entered mainstream debate and fostered more widespread attitude change in the profession (16).

\section{General issues}

There seem to be important differences in the approach of health professionals working with torture survivors in exile conditions compared with those working within the country where torture is happening as a part of ongoing civil conflict. In the latter circumstances political neutrality is practically impossible, and is commonly assumed to mask an allegiance to the status quo, as we have seen in illustrations above. In South Africa, issues of trust and security have excluded doctors and psychologists from work with activists unless they were judged to be actively committed to an anti-apartheid position (17).

Political investment has also tended to permeate judgement and decision-making in professional bodies and in the individual practitioners, and the road back to a more independent professional ethical position has been painful. It has been crucial, however, to establish the principle that there are no circumstances which justify the collaboration of health professionals with torturers.

The South African experience helps clarify a further point. Torture exerts its effects in society by being widely known in the repressed population but not openly revealed or opposed. As outlined in the Argentinian experience (18) it depends on a 'conspiracy of silence', sutained by fear or complicity. Doctors and other health workers inevitably see at first-hand the work of the torturers, and they bear a special ethical responsibility not only to refuse to collaborate but also to make the facts and their opposition public. Professional bodies have a responsibility to give public support to this endeavour. In South Africa open opposition and the investigation and publication of the facts challenged the legitimacy of the state's strategies and the impunity enjoyed by the security forces. International outrage and sanctions made torture politically uneconomical, and the state was forced to scale it back drastically. For these reasons the ethical responsibilities of the health professions in relation to torture need wide international promulgation. Gandhi has said 'Non-cooperation with evil is as important as co-operation with the good'; and it is clear that an unequivocal stand on principle does have an effect in society far wider than the bounds of the profession.

Terrence Dowdall, MA, is a Child Psychologist and Director of the Child Guidance Clinic, the University of Cape Town, Cape, South Africa. He is a member of the National Executive of the Emergency Services Group.

\section{References}

(1) De Beer C. The South African disease. Johannesburg: South African Research Services, 1984.

(2) Seedat A. Crippling a nation: health in apartheid South Africa. London: International Defence and Aid Fund, 1984.

(3) Steere J. Ethics in clinical psychology. Cape Town: Oxford University Press, 1984.

(4) Human Rights Commission. Anatomy of repression. Information manual M-1. Braamfontein: HRC, 1989.

(5) Human Rights Commission. Detention without trial. Fact paper FPl. Braamfontein: HRC, 1989.

(6) Mathews A. National security, morality and the courts. Paper presented at the 13th South African Law Conference, Durban, 1990.

(7) Detainees' Parents' Support Committee. Memorandum on security: police abuse of political detainees. Johannesburg: DPSC, 1982.

(8) Foster D, Sandler D. A study of detention and torture in South Africa: preliminary report. Cape Town: Institute of Criminology, University of Cape Town, 1985.

(9) Webster D. Repression and the State of Emergency. In: Moss G, Obery I, eds. South African review 4. Johannesburg: Ravan Press, 1987.

(10) Rayner M. Turning a blind eye? Medical accountability and the prevention of torture in South Africa. Washington: American Association for the Advancement of Science, 1987. 
(11) The Lawyers Committee for Civil Rights Under Law. Deaths in detention and South Africa's security laws. Washington DC: Lawyers Committee for Civil Rights Under Law, 1983.

(12) See reference (10): 28.

(13) Baxter L. Doctors on trial: Steve Biko, medical ethics and the courts. South African journal on human rights 1985; 1, 2: 137-151.

(14) Orr W. Detention, health and the media. Unpublished address delivered at University of Cape Town Medical School, July, 1990.

(15) Browde S. The treatment of detainees. Proceedings of the 1987 NAMDA Conference. Cape Town: NAMDA,
1987.

(16) Dowdall T. Torture and the helping professions in South Africa. In: Basoglu $\mathrm{M}$, ed. Torture and its consequences. London: Cambridge University Press (in press).

(17) Steere J, Dowdall T. On being ethical in unethical places: the dilemmas of South African clinical psychologists. Hastings Center report, 1990; 20, 2: 11-15.

(18) Kordon D, Edelman L. Observations on the psychopathological effects of social silencing concerning the existence of missing people. In: Kordon et al, eds. Psychological effects of political repression. Buenos Aires: Sudamerikane/planeta, 1988. 